\title{
BÚSQUEDA DE LA SOSTENIBILIDAD DEL AGUA
}

* Ing. Bolivar Dimos Astudillo M.Sc.

El $70 \%$ de la superficie terrestre se encuentra cubierta de agua, con un volumen de $1460 \times 106 \mathrm{~km}^{3}$, de los cuales el 2,07\% corresponde agua dulce. En este valor se encuentra el $2,05 \%$ que corresponden a los casquetes polares y glaciares. Para servir a los 6,5 millardos de personas que habitan el Planeta Azul. Queda el 0,015\% del agua existente, un volumen que corresponde a $220000 \mathrm{~km}^{3}$; en este valor se encuentran sumados el agua de los ríos, lagos, agua atmosférica y humedad del suelo, de esta cantidad el mayor volumen es utilizado para la producción de fibras vegetales, para provisión de alimento para la población. Figura 1.

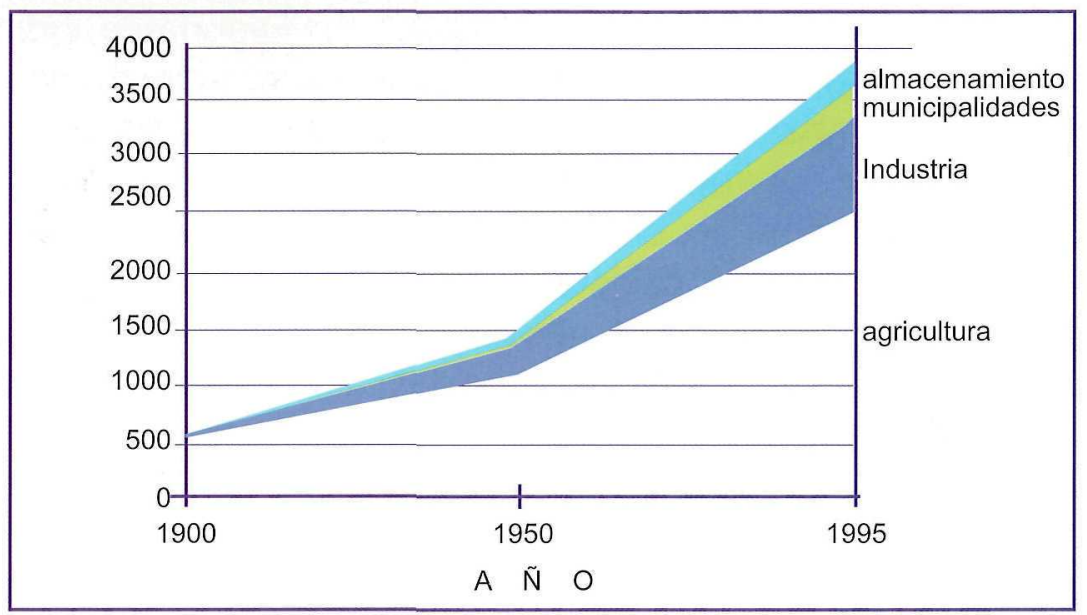

Figura 1. Crecimiento de diferentes usos del agua de 1900 a 1995. Dr. Huub Gijzen

Esta producción de fibras y de cada uno de los alimentos que diariamente se consumen, hace que los volúmenes de agua que se disponen por persona se eleven y no sean solamente los que se señalan como dotación, para Cuenca $=90 \mathrm{~m}^{3} / \mathrm{hab}$. año. Es entonces justificable señalar nuestra dependencia del agua y de su pureza.

Nuestro cuerpo, al igual que el planeta, está compuesto de este oro azul en un $70 \%$. Sobreviviremos gracias a su utilización moderada o la pureza que se mantenga a través del tiempo; por tanto, de su cuidado y calidad dependen nuestro equilibrio y salud. La Figura 1, presenta la evolución del uso del agua en 100 años, donde se puede advertir que la mayor cantidad del líquido ha sido utilizado para la agricultura, lo cual significa que analizados todos los usos para cada persona se necesita un total de casi $2000 \mathrm{~m}^{3}$ de agua al año, para sus actividades relacionadas con productos y alimentación. El momento que este valor llegue a descender a $1000 \mathrm{~m}^{3}$, se habrá llegado al campo del estrés ambiental, por lo que políticas de fuerza de los países desperdiciadores coaccionarán con el propósito de manejar el escaso recurso existente. Por esta razón, todos debemos colaborar con nuevas ideas y tecnologías ambientales que permitan disminuir el uso y contaminación del agua. Solo el eficiente uso de este recurso hará posible legar a nuestros hijos y a los hijos de nuestros hijos la posibilidad de vivir en un planeta que continúe siendo azul.

* Catedrático de tratamiento de aguas 